\title{
Preliminary experience in pulmonary metastatectomy
}

\author{
Sameh I Sersar ${ }^{1,2}$, Ibrahim M Yassin ${ }^{3,4^{*}}$ \\ From World Society of Cardiothoracic Surgeons 25th Anniversary Congress, Edinburgh \\ Edinburgh, UK. 19-22 September 2015
}

\section{Background/Introduction}

The surgical resection of pulmonary metastasis is not new it dates back to 1994 thanks to Blalock who resected lung metastases from colorectal cancer. He reported his preliminary results in 1947. Since then, there is a wide variation in the 5-year survival rate achieved by lung metastatectomies in different institutions. It varies between $9 \%$ to $45 \%$.

\section{Aims/Objectives}

We aimed to review our preliminary limited experience in pulmonary metastatectomies in KAMC; Makkah; Saudi Arabia in more than 3 years.

\section{Method}

This is a retrospective study including 21 patients who had pulmonary metastatectomy in KAMC; Makkah between 2012 January and June 2015.

\section{Results}

Our study included 21 patients who had lung metastases and were operated upon by thoracic surgeons. Females constituted more than 2/3 of this series. Mean age was 26 years. Mean follow up duration was 25 months. The commonest primary originated from the bones and rectosigmoid. Thirty five thoracic surgeries were required for those 21 cases. Twelve patients had one thoracic surgery, five had 2 surgeries, three had 3 surgeries and one had 4 surgeries. We used either VATS or thoracotomy in our lung metastatectomies. Only one third of the resected specimens were proved to be metastatic. No significant perioperative complications were reported in our series. No mortality was reported during the study period.

${ }^{3}$ Cardiac Surgery Department, Saud al-Babtin Cardiac Center (SBCC), AlDammam, 31463, KSA

Full list of author information is available at the end of the article

\section{Discussion/Conclusion}

Pulmonary metastatectomy can be performed safely either by VATS or through thoracotomy with acceptable results.

\section{Authors' details}

${ }^{1}$ Cardiothoracic Surgery, Mansoura University, 35516, Egypt. ${ }^{2}$ King Abdullah Medical City, Makkah 21955, Saudi Arabia. ${ }^{3}$ Cardiac Surgery Department, Saud al-Babtin Cardiac Center (SBCC), Al-Dammam, 31463, KSA.

${ }^{4}$ Cardiothoracic Surgery Department, Tanta University Hospitals, Tanta, 31111 Egypt.

Published: 16 December 2015

doi:10.1186/1749-8090-10-S1-A269

Cite this article as: Sersar and Yassin: Preliminary experience in pulmonary metastatectomy. Journal of Cardiothoracic Surgery 2015 10(Suppl 1):A269.
Submit your next manuscript to BioMed Central and take full advantage of:

- Convenient online submission

- Thorough peer review

- No space constraints or color figure charges

- Immediate publication on acceptance

- Inclusion in PubMed, CAS, Scopus and Google Scholar

- Research which is freely available for redistribution

Submit your manuscript at www.biomedcentral.com/submit
() Biomed Central 